\title{
Mortality, re-sprouting vigor and physiology of coppice stumps after mechanized cutting
}

\author{
Raffaele Spinelli $^{1}$ - Luigi Pari $^{2} \cdot$ Giovanni Aminti $^{1} \cdot$ Natascia Magagnotti $^{1}$. \\ Alessio Giovannelli ${ }^{1}$
}

Received: 30 July 2016 / Accepted: 21 October 2016/Published online: 6 February 2017

(C) INRA and Springer-Verlag France 2017

\begin{abstract}
- Key message Mechanized cutting may result in higher stump damage levels, especially if cutting is performed with shears. Nevertheless, stumps cut with mechanized technology do not show higher mortality rates than do stumps cut manually with a chainsaw. One-year growth is also unaffected, and so is nutrient balance within the stump.

- Context Coppice harvesting must be mechanized in order to modernize coppice management, so that it can grow along with the dynamic new bio-economy. However, foresters are concerned that mechanized cutting may result in higher stump
\end{abstract}

\section{Handling Editor: Erwin Dreyer}

Contribution of the co-authors All the authors worked at collecting, refining, and organizing the data, as well as in writing the paper and discussing its results. Dr. Spinelli, Dr. Giovannelli, and Mr. Aminti also worked at the statistical analysis of the data. The research project was coordinated by Dr. Spinelli

Raffaele Spinelli

spinelli@ivalsa.cnr.it

Luigi Pari

luigi.pari@entecra.it

Giovanni Aminti

aminti@ivalsa.cnr.it

Natascia Magagnotti

magagnotti@ivalsa.cnr.it

Alessio Giovannelli

giovannelli@ivalsa.cnr.it

1 CNR IVALSA, Via Madonna del Piano 10, I-50019 Sesto Fiorentino (FI), Italy

2 CREA ING, Via della Pascolare 16, Monterotondo Scalo (Roma), Italy damage levels, which may cause increased mortality and lower growth rates.

- Aims The goal of the study was to compare manual and mechanized cutting in terms of cut quality, stump damage levels, stump mortality, re-sprouting vigor, and shoot growth. - Methods The study was conducted in a classic Mediterranean coppice stand located in central Italy. The oak-dominated coppice was cut using a chainsaw (control), a disk saw and a shear. The experiment adopted a split-plot design, based on 5 plots divided into 15 subplots (1 subplot per plot and technology). Overall, 344 stumps were selected, tagged, and monitored over the first growing season after cutting. Stump size, cutting height, and cutting damage were determined right after cutting. At the end of the first growing season, the following parameters were also recorded: no. of shoots; height, diameter, and type of the tallest five shoots. Samples were collected from randomly selected stumps during the main phenological phases in order to determine the content of $\mathrm{C}, \mathrm{N}$, starch, and soluble sugar, as well as the $\mathrm{C} / \mathrm{N}$ ratio.

- Results Mortality ranged from 4 to $8 \%$. Re-sprouting was generally vigorous, with dominant shoots often exceeding the height of $1.5 \mathrm{~m}$ after 1 year. Cutting technology had a significant effect on cutting height and cutting damage, but it had no effect on mortality, re-sprouting vigor, and nutrient balance within the stumps, at least in the first growing season. Resprouting vigor depended mainly on species.

- Conclusion While it may result in higher stump damage levels, mechanized cutting does not seem to have any effects on coppice regeneration and growth, at least in the first year. Previous studies indicate that effects recorded during the first growing season may be representative of longer-term trends. The experiment will be continued to obtain additional confirmation.

Keywords Felling $\cdot$ Regeneration $\cdot$ Growth $\cdot$ Mortality $\mathrm{C} / \mathrm{N}$ ratio 


\section{Introduction}

Coppice forests represent an extreme example in the domestication of woodlands. Coppice management offers the benefits of short waiting time and simplified care, which make it very efficient in providing rural communities with firewood, posts, tool handles, and fencing materials (Buckley 1992). For this reason, coppice forests were widespread all over Europe until recent times, when industrialization transformed both the economy and the landscape of many regions (Coppini and Hermanin 2007). Nevertheless, coppice forests have survived in rural areas, because they are best suited to provide for the immediate material needs of a dense rural population (Wolfslehner et al. 2009). Today, coppice is still abundant in the Mediterranean and the Balkan regions (Jansen and Kuiper 2004), but it suffers from the competition of oil and plastic, which results in a reduced interest toward active coppice management (Hédl et al. 2010).

The rapidly expanding biomass economy represents an ideal opportunity for reviving coppice management (Matula et al. 2012). Biomass users need large amounts of low-quality wood at short intervals, which is what coppice was designed to produce. While new short-rotation coppice stands are being established on ex-arable land, existing coppice forests might represent an even larger source of raw material for the growing bio-economy. In fact, the increasing demand for food products has weakened both the financial and the ethical sustainability of short-rotation coppice (Glithero et al. 2013), leaving traditional coppice forests as a more desirable solution for matching the large feedstock demands of the modern bioeconomy (Ollikainen 2014).

Here, the attribute "modern" is key: an old production system can hardly satisfy the requirements of a modern user. Coppice forests can enjoy the benefits of the modern bioeconomy only if coppice management is modernized. For this reason, it is important to facilitate the transition of coppice management from a part-time rural activity to a modern industrial business. Mechanization may seem an obvious solution, because it compensates for the reduced availability of rural labor, with their propensity to perform heavy and lowpaying jobs. Much progress has already been made, with the massive introduction of modern forwarders and tower yarders in coppice harvesting operations (Spinelli et al. 2016). However, tree felling is still performed motor-manually in most cases (Spinelli et al. 2014a).

The presence of multiple stems on the same stump offers a serious challenge to the introduction of mechanized felling to coppice harvesting operations, because stem crowding hinders felling head movements, and can be handled by very compact units only (Suchomel et al. 2012). However, many studies have already shown that coppice felling can be mechanized if the right technology is applied with sufficient skill (McEwan et al. 2016). In that respect, the last hurdle is represented by the absolute need to prevent stump damage, in order to guarantee prompt regeneration. Forest regulations often prescribe that cuts must be as clean as possible, and cut height may not exceed $10 \mathrm{~cm}$ from the ground surface. Since mechanical felling cannot guarantee that these requirements are met, forest managers often forbid mechanized felling in their coppice forests and accept the higher cost of motor-manual felling.

Unfortunately, financial viability is not the only issue at stake. Manual felling is associated with the highest accident risk and accident severity, and it accounts for most of the fatal accidents recorded in forest operations (Albizu et al. 2013). Previous studies have shown that the introduction of mechanized felling may reduce accident rates by a factor of 4 (Bell 2002), and therefore replacing manual felling with mechanized felling is a strategic ethical requirement.

Such crucial issue must be solved, if coppice management has to be rescued from its slow decline. For this reason, a compromise must be found between ideal practice and the operational limits of mechanization. In fact, very few scientific papers offer reliable information about the effects of cut quality on stump mortality and re-sprouting vigor. Not only we cannot quantify the losses derived from mechanized cutting but we also cannot even state that losses actually occur, nor can we determine the physiological mechanisms eventually involved.

Re-sprouting vigor is strictly related to the carbon and nitrogen reserves of the stump at the time of cutting (Kays and Canham 1991). After wounding (i.e., cutting) occurs, the emission of new stems requires the mobilization of carbon reserves in the stump - and mainly the starch and the soluble sugar contained inside the parenchymatous rays of roots and stem. In contrast, $\mathrm{N}$ mobilization is seasonally programmed and less involved in the response of the plant to perturbations (Millard and Grelet 2010).

Previous studies have shown a positive relationship between carbon reserves and the mass of sprouts (Schier and Zasada 1973), leading to the formulation of the carbon allocation hierarchy hypothesis. Such hypothesis postulates that re-sprouting vigor is related to the availability of sufficient carbon reserves (Waring and Pitman 1985), which might be affected by the quality of cutting.

Therefore, the goals of this study were (1) to determine if mechanized cutting may affect the mortality and re-sprouting of coppiced stumps; (2) to gauge the magnitude of such effects, if present; (3) to analyze the effect of mechanized cutting on the carbon and nitrogen reserves of the stumps, in order to obtain an insight into long-term effects.

\section{Materials and methods}

The study was conducted in Italy, where coppice stands account for about half of the total forest area. With over 3 million hectares, Italy has the largest area of coppice forests in Europe 
after France, and it has a strategic interest in harnessing its large coppice resource to the development of a thriving bioenergy sector. The study was performed in a typical oakdominated coppice stand located at Roccaccia, near the historical town of Tarquinia in Central Italy $\left(42^{\circ} 34^{\prime} 46^{\prime \prime} \mathrm{N}, 11^{\circ} 75^{\prime}\right.$ $29^{\prime \prime} \mathrm{E}$ ). The main species were Turkey oak (Quercus cerris L.), downy oak (Q. pubescens L.), field maple (Acer campestris L.), narrow-leaf ash (Fraxinus angustifolia $\mathrm{Vahl}$ ), and manna ash (F. ornus L.), which represented 36, 7, 24, 16, and $4 \%$ of the stump numbers, respectively. The remaining $13 \%$ of the stumps were mock privet (Phyllirea angustifolia L.) and cornelian cherry (Cornus mas L.). Oaks and maples constituted the upper story, whereas ash, mock, privet, and cornelian cherry were part of the lower story. The understory was a typical consociation of black thorn (Prunus spinosa L.), butcher's broom (Ruscus aculeatus L.), and bladder senna (Colutea arborescens $\mathrm{L}$.). The diameter at breast height (DBH) of coppice stems ranged from 5 to $30 \mathrm{~cm}$, averaging $15 \mathrm{~cm}$. The new stand was 20 years old and was clearcut with a reserve of approximately 100 standards per hectare. All standards left during the previous rotation were removed. The stand was quite dense, and the harvest amounted to over 150 fresh $\mathrm{t} \mathrm{ha}^{-1}$. This figure included tops and branches, because whole-tree chipping was applied with the purpose of producing high-quality boiler fuel. Slope gradient averaged $20 \%$, which allowed easy access to ground-based harvesting equipment. In general, stand characteristics were considered representative of Mediterranean coppice stands, common to large parts of Italy, southern France, Spain, and the Balkans, although in myriads of local variations (Amorini et al. 1998).

Five contiguous sample plots were installed inside the compartment just before commercial harvesting. Each plot measured ca. $70 \mathrm{~m} \times 45 \mathrm{~m}$ and comprised of three 15 -m wide felling swathes, or subplots. Plots were joined side by side, so that the overall sample area was $70 \mathrm{~m}$ long and $225 \mathrm{~m}$ wide (i.e., $45 \mathrm{~m} \times 5$ plots). The experimental design was a typical split-plot, where three felling treatments were distributed randomly among the three subplots constituting each sample plot. In this case, the advantage of restricted randomization was to avoid poor allocation of treatments in the event of a spatial gradient in soil productivity, which is quite common in natural forests. Climate and exposure conditions were equal across all plots, and therefore, they did not constitute an expected source of variation.

The three treatments on test were (i) motor-manual felling with a chainsaw (control), (ii) mechanized felling with a highspeed circular saw, and (iii) mechanized felling with a hydraulic shear. The chainsaw was a Stihl MS440, powered by a 70$\mathrm{cm}^{3}$ two-stroke engine capable of delivering $4 \mathrm{~kW}$. The chainsaw was equipped with a $50-\mathrm{cm}$ bar (Fig. 1a). The high-speed circular saw (i.e., hot saw) was a GD350 model built by the Italian company COMAF and installed on a 17-t tracked excavator (Fig. 1b). Finally, the hydraulic shear was a single-
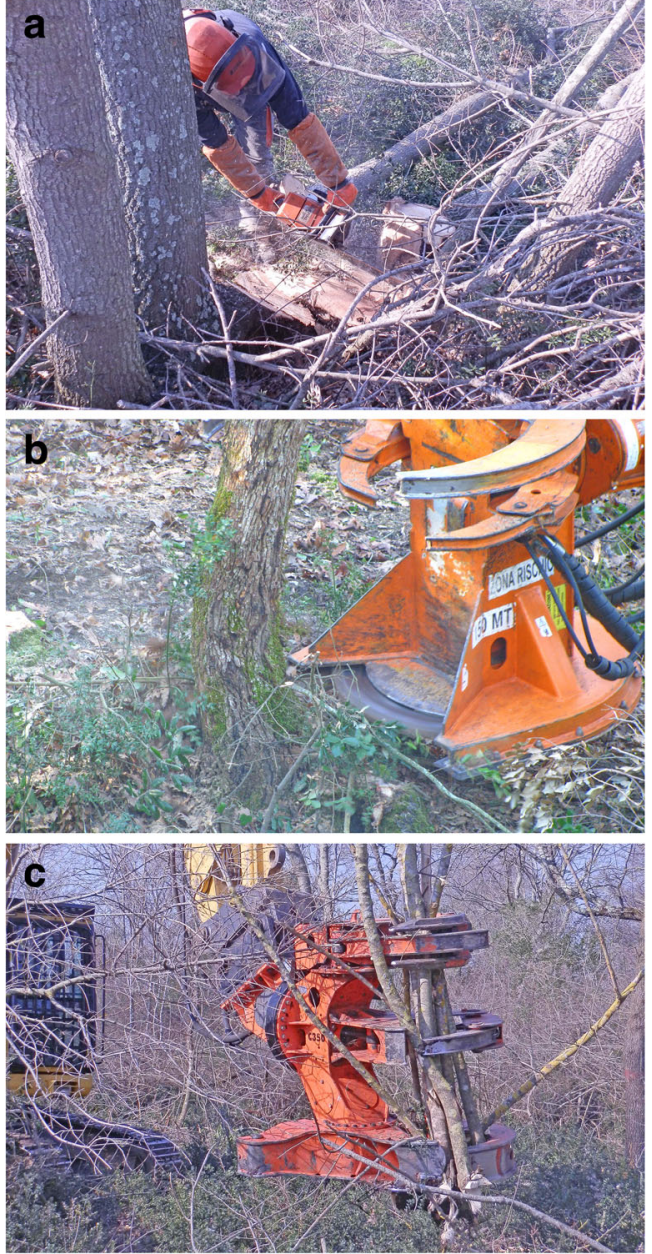

Fig. 1 The three cutting technologies on test: chainsaw (a on top), disk saw (b in the center), and shear (c at the bottom)

knife Woodcracker C model, built by the Austrian company Westtech and installed on a 21-t tracked excavator (Fig. 1c). All machines were operated by experienced professionals, who had run them for several years. The skills of study operators were considered representative of the region and were fairly similar between them. All sample plots were harvested on March 10 and 11, 2015, when the trees were still dormant and the ground was dry. The cutting dates were selected specifically for removing any cutting season effects on resprouting, because coppicing at the end of the dormant season is considered ideal for promoting vigorous regeneration (Ducrey and Turrel 1992).

The individual stump represented the observational unit for this study. For the purpose of the study, the stump was defined as the visible base of an older parent tree that supported two or more stems. Stems could be placed at some distance from each other, but they were still connected at the old root base, which defined the extent of the individual stump. Old stumps had been coppiced several times: they could be very large and were often hollow in the center. After cutting, between 13 and 34 stumps were randomly selected within each subplot, 
depending on local stand density. The total number of sample stumps amounted to 344 units or 102, 122, and 120 for the chainsaw, the disk saw, and the shear treatment, respectively. The goal was to follow up the re-sprouting of at least 100 stumps per treatment, and therefore a larger number of stumps were initially recruited in order to compensate for the eventual mortality. Each stump was attributed a sequential identification number, clearly marked on a highly visible yellow plastic tag driven deep into the soil right by the stump. For each stump, we recorded the following characteristics: cut quality, presence and quality of regeneration after the first growing season, and biochemical indicators of stress.

Stump characteristics and cut quality were determined immediately after cutting, at the time of selecting and marking the stumps. Each stump was characterized for species; circumference at cut level; minimum and maximum cut height, measured from ground level; presence of cavities in the stump center; and cutting damage. The latter was attributed to one of the following classes: clean cut (no damage), pullout (fibers being pulled off the cut stem), crack (any splitting of the stump), and stump pull (fibers being pulled off the cut stump).

Marked stumps were inspected again in early February 2016, in order to check for re-sprouting. Stumps without any shoots were classed as dead and were used to estimate mortality rates. When shoots were present, the following parameters were recorded: no. of shoots taller than $30 \mathrm{~cm}$, height of the five tallest shoots, diameter of the five tallest shoots taken at $30 \mathrm{~cm}$ aboveground, insertion of the five tallest shoots (i.e., proventitious shoot, adventitious shoot, or root sucker), and presence of browsing. In order to minimize browsing damage, all tagged stools were treated with deer repellent three times during the first growing season. Full coverage was provided in May (twice) and late September, when shoots were most attractive and/or when other food sources were scarce.

Acknowledging that 1-year re-sprouting may not offer a comprehensive picture of stress differences between treatments, the study endeavored to determine the $\mathrm{C} / \mathrm{N}$ ratio and the sugar type present in the stumps during the main phenological phases. The assumption was that a badly mauled stump might still re-sprout vigorously but at the cost of an excessive depletion of its own reserves and - converselythat less abundant re-sprouting might be compensated by a smaller depletion of the stump reserves, which may be indicative of better long-term performance.

For this purpose, samples were collected from 71 stumps, as resulting from the random selection of four to five stumps per subplots. Sample selection was random, but preference was given to the dominant species (oaks), which represented $60 \%$ of the total. Sample collection was repeated four times, once for each phenological phase, namely, onset of cambium activity right after felling, exponential growth, offset, and dormancy. Therefore, the total number of samples amounted to 284. Each sample consisted of a 5-cm long helical core, obtained from drilling the outermost part of the stump with a 6-mm wood drill bit, working perpendicularly to the surface of the ground. The rotation speed of the drill was maintained below $60 \mathrm{rpm}$ in order to avoid heating. Samples were extracted from the conducting area of sapwood and were composed of the most recent tree rings. Sample weight ranged from 100 to $250 \mathrm{mg}$ (fresh weight). After collection, samples were placed in plastic tubes and stored inside a cooler, at a temperature of $4{ }^{\circ} \mathrm{C}$. The cooler was moved to the laboratory within $6 \mathrm{~h}$ from sample collection, and the tubes were stored at $-80{ }^{\circ} \mathrm{C}$ until analysis. Sample preparation included freeze drying at $-50{ }^{\circ} \mathrm{C}$ for $96 \mathrm{~h}$ and milling with a Retsch ZM 200 centrifugal mill (Emiliani et al. 2011).

Soluble carbohydrates were extracted at room temperature with $5 \mathrm{ml}$ of deionized water ( $\mathrm{pH} \mathrm{7}$ ) added to $40 \mathrm{mg}$ of powder. The homogenate was placed in a $2 \mathrm{ml}$ polypropylene Spin-X centrifuge tube equipped with a $0.22-\mu \mathrm{m}$ cellulose acetate filter and centrifuged at $10,000 \times g$ at $5{ }^{\circ} \mathrm{C}$ for $10 \mathrm{~min}$ (Giovannelli et al. 2011). The surnatant was analyzed using a Perkin Elmer binary LC pump 250 equipped with an ISS101 automatic injection system. The column was an $8-\mathrm{mm} \times 300$ mm Shodex Sugar SC 1011 and was maintained at $80{ }^{\circ} \mathrm{C}$ using a water column heater module.

Pellets deriving from soluble sugar extraction were used for starch analysis following the procedure proposed by Deslauriers et al. (2014). The starch was dissolved with acetate buffer ( $\mathrm{pH} \mathrm{5)}$ and digested with an a-amylase solution at $2000 \mathrm{U} \mathrm{mL}^{-1}$ and amyloglucosidase at $10 \mathrm{U} \mathrm{mL}^{-1}$. Color reagent and $75 \% \mathrm{H}_{2} \mathrm{SO}_{4}$ were added to the solution for staining. Starch was assessed using a spectrophotometer at $533 \mathrm{~nm}$.

Total organic $\mathrm{C}$ and total $\mathrm{N}$ were determined on 20-mg dry wood powder samples by dry combustion with a Carlo Erba NA 1500 CHSN Analyzer (D'Acqui et al. 2010). Each analysis was replicated twice and the mean value was used for statistical analysis.

Data were analyzed statistically using SAS Statview, Minitab 16, and R for Excel, depending on the analytical technique. As a first step, descriptive statistics were drawn. The distribution of data was inspected visually, before performing specific statistical tests to gauge deviation from normality (Levene's test). Homoscedasticity was checked using Bartlett's test. The significance of the differences between mean values for different options was tested through the analysis of variance (ANOVA) or covariance (ANCOVA), if the parametric assumptions had not been violated. In that case, differences were pinpointed on treatments using TukeyKramer and Fisher's LSD post hoc tests. In contrast, if the parametric assumptions had been violated, non-parametric techniques were used (Kruskal-Wallis and Mann-Whitney tests). The significance of any differences between distributions was checked using a classic $\chi^{2}$ test. Linear regression analysis allowed testing the relationship between re-sprouting vigor and selected independent variables, such as stump size, 
species, and treatment. Indicator variables were used to introduce the effect of categorical variables (i.e., species) when exploring the relationship between re-sprouting vigor and stump size (Olsen et al. 1998).

\section{Results}

Field measurement showed that cutting height was significantly larger for the shear, compared with the chainsaw and the disk saw (Table 1). The effect of felling technology accounted for $18 \%$ of the variation in the cutting height data, and it was highly significant ( $p$ value $<0.0001$ ). Regression analysis found no relationship between cutting height and stump circumference $\left(\mathrm{R}^{2}<0.1\right)$. Stump circumference was even across all treatments and changed with species only, which accounted for $14 \%$ of the variation in the data ( $p$ value $<0.0001)$. Mean stump circumference was largest for the oaks $(236 \mathrm{~cm})$, smallest for the maple $(166 \mathrm{~cm})$, and intermediate for the ash $(207 \mathrm{~cm})$. That was consistent with the ecology of the different species and with the two-storied structure of the stand, dominated by oak trees.

Cut quality was strongly and significantly affected by cutting technology $\left(\chi^{2}=320, p\right.$ value $\left.<0.0001\right)$. Each technology had its own specific quality mark: the chainsaw produced a significantly larger proportion of clean cuts, compared with all other technologies; the disk saw produced a significantly larger proportion of pullouts, i.e., of fiber pulled from the butt of the felled tree (Fig. 2). In the specific case of the disk saw, pullout consisted mostly of fine fibers, resulting in a "hairy" cut surface. Finally, the shear produced a significantly larger

Table 1 Characteristics of the stumps at the time of cut, separately by treatment type $(n=344)$

\begin{tabular}{|c|c|c|c|c|}
\hline & Mean & $\mathrm{SD}$ & Min & Max \\
\hline \multicolumn{5}{|c|}{ Maximum height (cm) } \\
\hline Chainsaw & $9.4^{\mathrm{a}}$ & 3.9 & 2 & 27 \\
\hline Disk saw & $10.4^{\mathrm{a}}$ & 6.2 & 0 & 33 \\
\hline Shear & $15.2^{\mathrm{b}}$ & 7.1 & 3 & 40 \\
\hline \multicolumn{5}{|c|}{ Minimum height $(\mathrm{cm})$} \\
\hline Chainsaw & $4.2^{\mathrm{a}}$ & 2.0 & 0 & 10 \\
\hline Disk saw & $4.9^{\mathrm{a}}$ & 4.3 & 0 & 29 \\
\hline Shear & $7.8^{\mathrm{b}}$ & 4.6 & 1 & 24 \\
\hline \multicolumn{5}{|c|}{ Circumference at cut level $(\mathrm{cm})$} \\
\hline Chainsaw & $210^{\mathrm{a}}$ & 75 & 70 & 410 \\
\hline Disk saw & $213^{\mathrm{a}}$ & 88 & 65 & 415 \\
\hline Shear & $207^{\mathrm{a}}$ & 86 & 40 & 460 \\
\hline
\end{tabular}

Different superscript letters for the technology types indicate a statistically significant difference between treatments for $\alpha<0.05$

$S D$ standard deviation

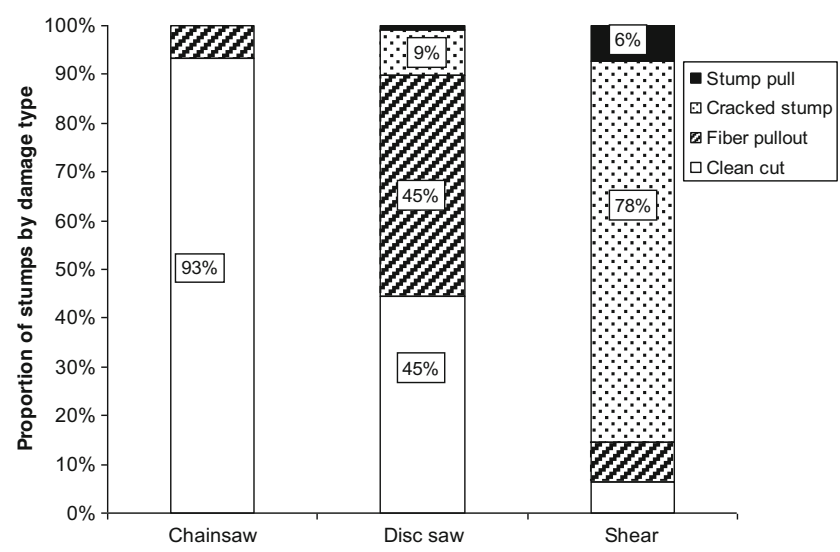

Fig. 2 Percent breakdown of cut stumps by cut quality, for the three cutting technologies on test (i.e., chainsaw, disk saw, and shear)

proportion of crack and stump pull, resulting in a more severe damage level than recorded for any of the other technologies.

Nevertheless, mortality after the first year was independent of cutting technology $(p=0.2510)$, and amounted to 7.8, 4.4, and $4.8 \%$, respectively, for the chainsaw, the disk saw, and the shear treatment. In fact, a comparison between dead and regenerated stumps failed to detect any significant differences in terms of cutting height and circumference. However, statistical analysis showed that the frequency of stump pull was five times higher among the dead stumps, and that this difference accounted for $70 \%$ of the chi-square value $\left(\chi^{2}=21.802 ; p\right.$ value $<0.0001$ ).

After 1 year, re-sprouting was measured on a total of 313 stumps, which carried 6481 shoots. Diameter, height, and insertion type were determined for 1502 dominant shoots instead of 1565 (i.e., 313 stumps $\times 5$ shoots), because 5 shoots were not available on every stump. The application of repellent was only partially successful, because one stump out of four showed signs of browsing. However, browsing interested less than half of the total number of shoots and was complete (all shoots interested) on 5\% of the stumps, only. Specific preference was evident: while $58 \%$ of the ash stumps showed signs of browsing, only $4 \%$ of the oak stumps did. Maple was in between, with 35\% of the stumps showing signs of browsing. However, browsing only occurred very early in the season, and it affected young shoots almost exclusively. As a result, stumps had the chance to produce new shoots or concentrate their growth on the remaining ones. Furthermore, the presence of browsing differed with the species but not with the treatment. Browsing damage was evenly distributed across all treatments, and therefore, it did not affect the results of the technology comparison.

Re-sprouting vigor was significantly associated with the species and the size of the stumps, as expressed by their circumference (Table 2). Maple stumps produced between 1.5 and 2 times more shoots than either oak or ash stumps. However, maple shoots were shorter and had a smaller diameter than oak or ash shoots. Oak stumps produced the largest shoots, for both diameter and height (Table 3). Stump 
Table 2 The effect of treatment type, species, and stump circumference on the main indicators of re-sprouting vigor as tested through the analysis of covariance (ANCOVA)

\begin{tabular}{|c|c|c|c|c|c|}
\hline & DF & SS & $\eta^{2}$ & F value & $p$ value \\
\hline \multicolumn{6}{|c|}{ Number of shoots taller than $30 \mathrm{~cm}-$ square root transformed } \\
\hline Treatment & 2 & 12.8 & 0.02 & 3.124 & 0.0455 \\
\hline Species & 2 & 129.7 & 0.16 & 31.711 & $<0.0001$ \\
\hline Circumference & 1 & 57.8 & 0.07 & 28.26 & $<0.0001$ \\
\hline Residual & 291 & 595.3 & 0.75 & & \\
\hline \multicolumn{6}{|c|}{ Mean shoot diameter at $30 \mathrm{~cm}$ from the ground $(\mathrm{mm})$} \\
\hline Treatment & 2 & 16.8 & 0.00 & 0.349 & 0.7055 \\
\hline Species & 2 & 4620.7 & 0.37 & 95.762 & $<0.0001$ \\
\hline Circumference & 1 & 953.9 & 0.08 & 39.537 & $<0.0001$ \\
\hline Residual & 291 & 7020.7 & 0.56 & & \\
\hline \multicolumn{6}{|c|}{ Mean shoot height $(\mathrm{cm})$ - square root transformed } \\
\hline Treatment & 2 & 13.3 & 0.01 & 1.630 & 0.1978 \\
\hline Species & 2 & 495.3 & 0.27 & 60.473 & $<0.0001$ \\
\hline Interaction & 1 & 144.5 & 0.08 & 35.286 & $<0.0001$ \\
\hline Residual & 291 & 1191.6 & 0.65 & & \\
\hline
\end{tabular}

Diameter and height as measured on the five tallest shoots per stump; circumference measured at cut level; results for the interaction terms are not reported, because they did not result significant; Treatment is the test treatment, i.e., the cutting technology (chainsaw, disk saw, or shear)

$D F$ degrees of freedom, $S S$ sum of squares, $\eta^{2}$ ratio between the SS for the specific effect and the total SS

circumference had no effect on the number of shoots produced, but it affected the diameter and the height of dominant

Table 3 Mean values for the main indicators of re-sprouting vigor reported by species and treatment $(n=296)$

\begin{tabular}{|c|c|c|c|c|c|c|}
\hline & \multicolumn{2}{|l|}{ Oak } & \multicolumn{2}{|l|}{ Maple } & \multicolumn{2}{|l|}{ Ash } \\
\hline & Mean & SD & Mean & SD & Mean & SD \\
\hline \multicolumn{7}{|c|}{ Number of shoots taller than $30 \mathrm{~cm}$} \\
\hline Chainsaw & $13.7^{\mathrm{a}}$ & 7.7 & $37.5^{\mathrm{a}}$ & 19.6 & $18.0^{\mathrm{ab}}$ & 12.6 \\
\hline Disk saw & $15.8^{\mathrm{ab}}$ & 9.4 & $23.4^{\mathrm{b}}$ & 19.3 & $13.1^{\mathrm{a}}$ & 8.2 \\
\hline Shear & $18.7^{\mathrm{b}}$ & 10.3 & $28.6^{\mathrm{ab}}$ & 15.8 & $25.6^{\mathrm{b}}$ & 21.3 \\
\hline \multicolumn{7}{|c|}{ Mean shoot diameter at $30 \mathrm{~cm}$ from the ground $(\mathrm{mm})$} \\
\hline Chainsaw & 17.6 & 6.7 & 6.3 & 1.9 & 12.4 & 5.7 \\
\hline Disk saw & 17.3 & 6.2 & 5.3 & 1.9 & 13.9 & 4.8 \\
\hline Shear & 18.0 & 6.1 & 6.1 & 2.1 & 14.0 & 5.5 \\
\hline \multicolumn{7}{|c|}{ Mean shoot height (cm) } \\
\hline Chainsaw & 184 & 63 & 101 & 27 & 114 & 44 \\
\hline Disk saw & 180 & 59 & 83 & 34 & 136 & 48 \\
\hline Shear & 197 & 63 & 100 & 36 & 136 & 46 \\
\hline
\end{tabular}

Diameter and height as measured on the five tallest shoots per stump; different superscript letters for the technology types indicate a statistically significant difference for $\alpha<0.05$ (reported for number of shoots only, since no significant differences were determined for the other cases)

Oak consolidated data for $Q$. cerris L. and Q. pubescens L., Ash consolidated data for F. angustifolia Vahl and F. ornus L., SD standard deviation shoots. Larger stumps produced taller dominant shoots, with a larger diameter (Fig. 3). While this was true for all species, diameter and height increments were different for the different species: they were largest for the oaks and smallest for the maple. Regression analysis confirmed that stump circumference and species effects were both significant but separate (Table 4).

Felling technology had no effect on shoot diameter or height, but it had a weak and significant effect on the number of shoots. Cutting with shears resulted in a significant increase in the number of shoots growing on oak stumps, which was 18 and $36 \%$ larger than found on oak stumps cut with the disk saw and the chainsaw, respectively. Maple and ash stumps cut with the disk saw presented fewer shoots than did maple and ash stumps cut with either the chainsaw or the shear, and the difference varied between 18 and $48 \%$.

Felling technology also had an effect on the insertion of dominant shoots. Cutting with the shear reduced by a factor of 6 the presence of dominant adventitious shoots on ash stumps, which had a higher propensity for re-sprouting from the callus compared with oak and maple stumps (Table 5). A similar effect was also found for oak stumps, although not as strong as for maple stumps. Conversely, cutting with a chainsaw
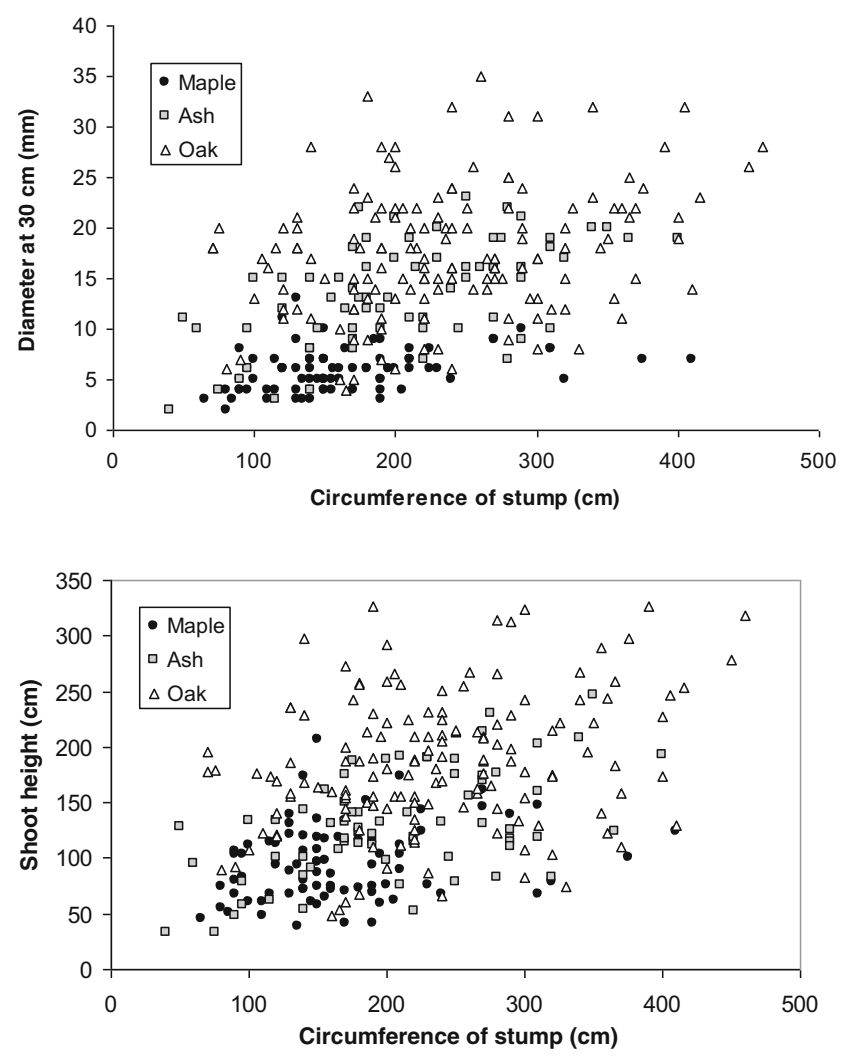

Fig. 3 Relationship between stump circumference and shoot diameter at the height of $30 \mathrm{~cm}$ from insertion (above) or total shoot height (below), for the tree main commercial species. Notes: diameter and height as measured on the five tallest shoots per stump; circumference at cut level; Oak consolidated data for $Q$. cerris L. and $Q$. pubescens L., Ash consolidated data for F. angustifolia Vahl and F. ornus L. 
Table 4 Regression equations for predicting shoot diameter and height as a function of stump circumference and species

Mean shoot diameter at $30 \mathrm{~cm}$ from the ground $(\mathrm{mm})$

Diameter $=\mathrm{a}+\mathrm{b}$ circumference $+\mathrm{c}$ maple $+\mathrm{d}$ oak

$\mathrm{R}^{2}$ adjusted $=0.531, n=297$

$\begin{array}{lllll} & \text { Coefficient } & \text { SE } & \text { F value } & p \text { value } \\ \text { A } & 8.789 & 0.963 & 9.131 & <0.0001 \\ \text { B } & 0.023 & 0.004 & 6.320 & <0.0001 \\ \text { C } & -6.727 & 0.817 & -8.231 & <0.0001 \\ \text { D } & 3.326 & 0.727 & 4.577 & <0.0001\end{array}$

Mean shoot height $(\mathrm{cm})$

Height $=\mathrm{a}+\mathrm{b}$ circumference $+\mathrm{c}$ maple $+\mathrm{d}$ oak

$\mathrm{R}^{2}$ adjusted $=0.424, n=297$

$\begin{array}{lllll} & \text { Coefficient } & \text { SE } & \text { F value } & p \text { value } \\ \text { A } & 84.732 & 9.655 & 8.776 & <0.0001 \\ \text { B } & 0.218 & 0.037 & 5.947 & <0.0001 \\ \text { C } & -24.683 & 8.198 & -3.011 & 0.0028 \\ \text { D } & 49.296 & 7.290 & 6.762 & <0.0001\end{array}$

Diameter and height as measured on the five tallest shoots per stump; circumference of the stump at cut level, in $\mathrm{mm}$; Maple $=1$ if species is maple, 0 if not; Oak $=1$ if species is oak (Q. cerris L. or Q. pubescens $\mathrm{L}$.), 0 if not

$S E$ standard error

seemed to promote the development of adventitious shoots on all species. Since insertion type was determined for the dominant shoots only, it was impossible to determine if cutting technology affected the emission or the dominance of a certain type of shoots, but the result was unequivocal: the type of dominant shoots was associated with felling technology.

Further analyses were conducted after replacing felling technology with damage class as the main independent variable, but none pointed at any significant differences, and therefore, the results are not reported in this manuscript.

Mechanized cutting had no effect on total $\mathrm{N}$ and carbon accumulation in the stump, which followed a classic seasonal pattern (Table 6). Total $\mathrm{N}$ concentration and $\mathrm{C} / \mathrm{N}$ ratio showed a substantial steady state for $\mathrm{N}$ content in the stumps (Figs. 4 and 5), which varied only with species: oak stumps had higher $\mathrm{N}$ content $\left(0.27 \mathrm{mg} \mathrm{g}^{-1}\right.$ dry weight) than did ash and maple stumps ( 0.19 and $0.21 \mathrm{mg} \mathrm{g}^{-1}$ dry weight, respectively). After cutting, the soluble sugar and carbon reserves in the ray parenchyma of the stumps decreased, following a well-defined seasonal pattern ( $p$ value $<0.001$ ) (Figs. 6 and 7). The highest decrease was recorded between April and July, during sprouting and spring growth (83 and $24 \%$ of reduction in the starch and soluble sugar content, respectively). The amount of carbon reserves in the stumps depended on the species $(p$ value $=0.03$ and $<0.0001$ for soluble sugar and starch, respectively). Ash showed higher starch and soluble sugar content than did oak and maple. The decrease of the carbon reserves occurred at different rates in different species (time $\times$ specie, $p$
Table 5 Percent distribution of different shoot types (adventitious, proventitious, and root sucker) by species and cutting treatment

Adventitious shoots Proventitious shoots Root suckers

$\begin{array}{lcrl}\text { All treatments together }- \text { by species } & \\ \text { Species }-\chi^{2}=10.491 ; p \text { value }= & 0.033 \\ \text { Oak } & 11.0 & 80.9 & \\ \text { Maple } & 12.3 & 82.9 & 4.1 \\ \text { Ash } & \mathbf{1 6 . 0} & 78.8 & 5.2\end{array}$

Oak only_by treatment

Treatments $-\chi^{2}=17.008 ; p$ value $=0.002$

$\begin{array}{lrrr}\text { Chainsaw } & \mathbf{1 6 . 8} & 73.5 & 9.7 \\ \text { Disk } & 9.5 & 82.1 & 8.4 \\ \text { Shear } & \mathbf{6 . 5} & 88.1 & 5.4\end{array}$

Maple only_by treatment

Treatments- $\chi^{2}=9.571 ; p$ value $=0.048$

$\begin{array}{llll}\text { Chainsaw } & \mathbf{1 7 . 8} & 74.8 & 7.4\end{array}$

$\begin{array}{llll}\text { Disk } & 9.4 & 87.7 & 2.9\end{array}$

$\begin{array}{llll}\text { Shear } & 9.7 & 86.3 & 4.0\end{array}$

Ash only-by treatment

Treatments $-\chi^{2}=31.671 ; p$ value $=0.000$

$\begin{array}{lrrr}\text { Chainsaw } & 23.7 & 69.1 & 7.2 \\ \text { Disk } & 23.3 & 69.7 & 7.0 \\ \text { Shear } & \mathbf{3 . 6} & 94.2 & \mathbf{2 . 2}\end{array}$

Insertion as measured on the five tallest shoots per stump; numbers in bold represent the largest contributors to the $\chi^{2}$

Oak consolidated data for $Q$. cerris L. and Q. pubescens L., Ash consolidated data for $F$. angustifolia Vahl and $F$. ornus L.

value $<0.001$ ). The concentration of soluble sugar remained stable in ash stumps during the whole year but decreased strongly in response to cutting in oak and maple stumps.

\section{Discussion and conclusions}

Other studies have shown that shears used in coppice produce tall stumps (Spinelli et al. 2007), and that these stumps are taller than those obtained with chainsaws or disk saws under the same conditions (Schweier et al. 2015). Theoretically, shears could cut nearer to the ground compared with chainsaws, because they are not as vulnerable to the contact with soil. However, shears are less powerful than chainsaws and disk saws of the same size and may be forced to cut higher when used on large trees in order to attack the stem at a point where diameter is smaller and within the capacity of the shear (Schweier et al. 2015). If that was the case of this study, then one should observe a direct relationship between stump diameter and cutting height (Giudici and Zingg 2005). However, that did not verify: in no case, cutting height was related to stump diameter, nor was it systematically associated with mechanical cutting (Pyttel et al. 2013). In fact, the disk saw 
Table 6 Significance of the main factors affecting stump nutrient content as tested through repeated-measures ANOVA

\begin{tabular}{|c|c|c|c|c|c|}
\hline & DF & SS & $\eta^{2}$ & F value & $p$ value \\
\hline \multicolumn{6}{|l|}{ Starch } \\
\hline Intercept & 1 & $19,978.1$ & 0.79 & 211.308 & $<0.0001$ \\
\hline Treatment & 2 & 85.2 & 0.00 & 0.450 & 0.6415 \\
\hline Species & 2 & 1871.6 & 0.07 & 9.898 & 0.0005 \\
\hline Treat $\times$ species & 4 & 352.6 & 0.01 & 0.933 & 0.4580 \\
\hline Residual & 31 & 2930.9 & 0.12 & & \\
\hline Time & 3 & $27,547.9$ & 0.84 & 222.673 & $<0.0001$ \\
\hline Time $\times$ treat & 6 & 101.4 & 0.00 & 0.410 & 0.8708 \\
\hline Time $\times$ species & 6 & 804.5 & 0.02 & 3.251 & 0.0060 \\
\hline Time $\times$ treat $\times$ species & 12 & 466.8 & 0.01 & 0.943 & 0.5081 \\
\hline Residual & 93 & 3835.2 & 0.12 & & \\
\hline \multicolumn{6}{|l|}{ Soluble sugar } \\
\hline Intercept & 1 & $22,824.8$ & 0.78 & 122.950 & $<0.0001$ \\
\hline Treatment & 2 & 603.9 & 0.02 & 1.627 & 0.2216 \\
\hline Species & 2 & 1534.2 & 0.05 & 4.132 & 0.0315 \\
\hline Treat $\times$ species & 4 & 408.6 & 0.01 & 0.550 & 0.7010 \\
\hline Residual & 20 & 3712.9 & 0.13 & & \\
\hline Time & 3 & 4103.7 & 0.49 & 32.140 & $<0.0001$ \\
\hline Time $\times$ treat & 6 & 141.8 & 0.02 & 0.555 & 0.7640 \\
\hline Time $\times$ species & 6 & 1251.5 & 0.15 & 4.901 & 0.0004 \\
\hline Time $\times$ treat $\times$ species & 12 & 405.0 & 0.05 & 0.793 & 0.6556 \\
\hline Residual & 60 & 2553.7 & 0.30 & & \\
\hline \multicolumn{6}{|l|}{ Nitrogen } \\
\hline Intercept & 1 & 4.819 & 0.92 & 438.319 & $<0.0001$ \\
\hline Treatment & 2 & 0.024 & 0.00 & 1.113 & 0.3482 \\
\hline Species & 2 & 0.125 & 0.02 & 5.690 & 0.0111 \\
\hline Treat $\times$ species & 4 & 0.025 & 0.00 & 0.562 & 0.6932 \\
\hline Residual & 20 & 0.220 & 0.04 & & \\
\hline Time & 3 & 0.018 & 0.05 & 1.523 & 0.2177 \\
\hline Time $\times$ treat & 6 & 0.032 & 0.10 & 1.381 & 0.2370 \\
\hline Time $\times$ species & 6 & 0.026 & 0.08 & 1.110 & 0.3671 \\
\hline Time $\times$ treat $\times$ species & 12 & 0.022 & 0.07 & 0.463 & 0.9284 \\
\hline Residual & 60 & 0.235 & 0.71 & & \\
\hline \multicolumn{6}{|l|}{$\mathrm{C} / \mathrm{N}$ ratio } \\
\hline Intercept & 1 & $4,863,101$ & 0.87 & 159.336 & $<0.0001$ \\
\hline Treatment & 2 & 16,402 & 0.00 & 0.269 & 0.7671 \\
\hline Species & 2 & 66,829 & 0.01 & 1.095 & 0.3538 \\
\hline Treat $\times$ species & 4 & 50,960 & 0.01 & 0.417 & 0.7941 \\
\hline Residual & 20 & 610,423 & 0.11 & & \\
\hline Time & 3 & 31,943 & 0.02 & 0.536 & 0.6595 \\
\hline Time $\times$ treat & 6 & 22,478 & 0.02 & 0.189 & 0.9789 \\
\hline Time $\times$ species & 6 & 68,673 & 0.05 & 0.576 & 0.7479 \\
\hline Time $\times$ treat $\times$ species & 12 & 124,334 & 0.09 & 0.521 & 0.8926 \\
\hline Residual & 60 & $1,192,324$ & 0.83 & & \\
\hline
\end{tabular}

$D F$ degrees of freedom, $S S$ sum of squares, $\eta^{2}$ ratio between the SS for the specific effect and the total SS (mechanical felling) did not produce taller stumps than did the chainsaw (manual felling), which is consistent with the findings of previous studies, although not specific to coppice operations (Hall and Han 2006). A better explanation for the taller stumps produced by the shear is the specific cutting mechanism, which requires engulfing the stem within the full 


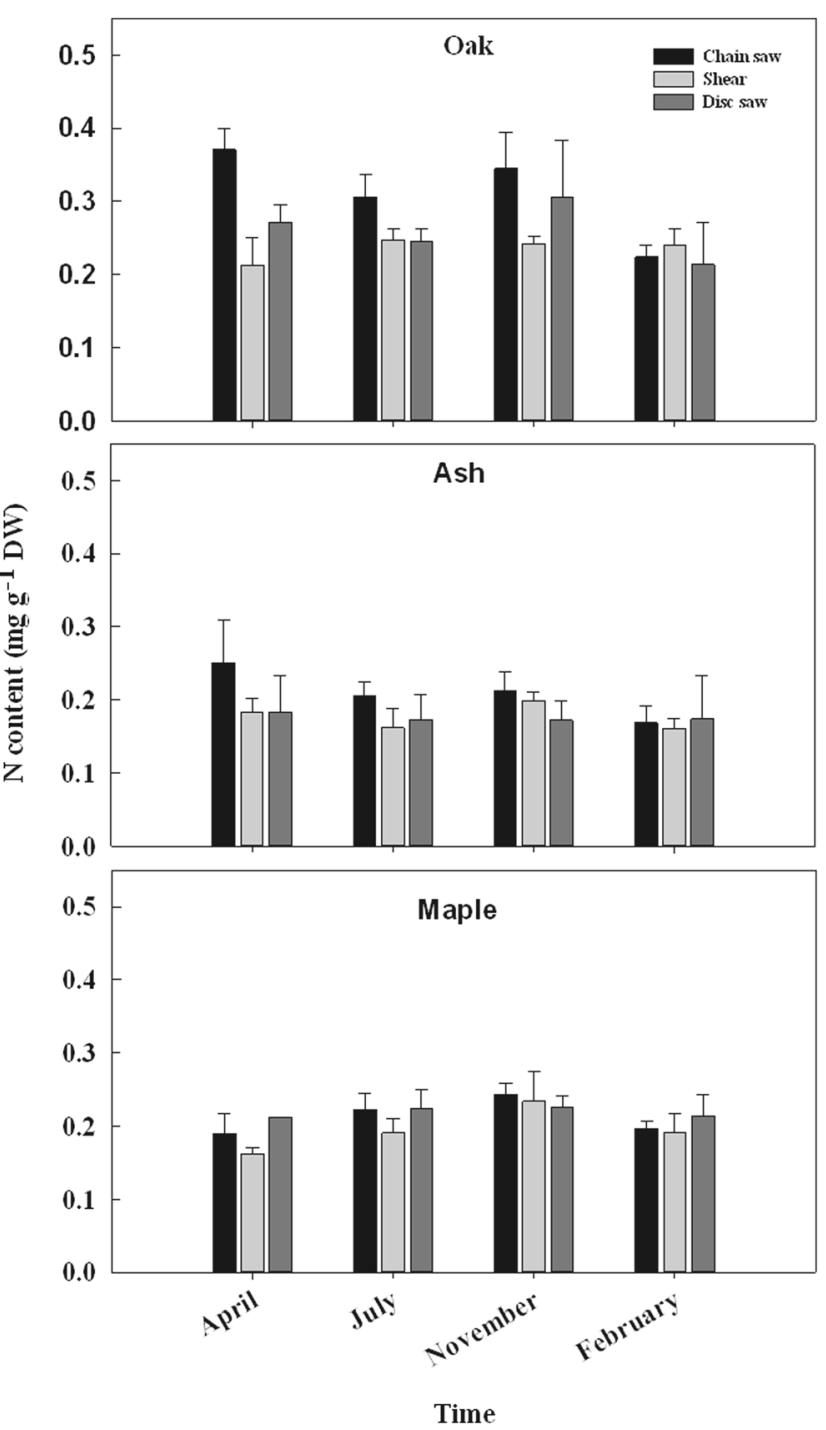

Fig. $4 \mathrm{~N}$ concentration in the stumps (mg N per g of dry stump weight) by species, treatment, and month/phenological phase. Note: phenological phases: April $=$ onset after cut, July $=$ exponential growth, November $=$ offset, February $=$ dormancy

arc described by the closing blades. That might be difficult to achieve when too close to the ground, near the insertion of the stems on the stump. In any case, cutting height is likely affected by a combination of factors, including machine type, tree species, stump diameter, and slope gradient (Han and Renzie 2005).

Corroboration from previous studies excludes that the results obtained from this experiment can be attributed to the specific machines, operators, or practices observed in this test and allows generalization. Such corroboration is also available for the higher damage level associated with the use of shears (De Souza et al. 2016). Shears produce compression stress (McNeel and Czerepinski 1987), which explains both the high incidence of damage and its specific type. Previous studies have shown that the most severe damage types, i.e., crack and stump pull, may be observed on a large proportion of

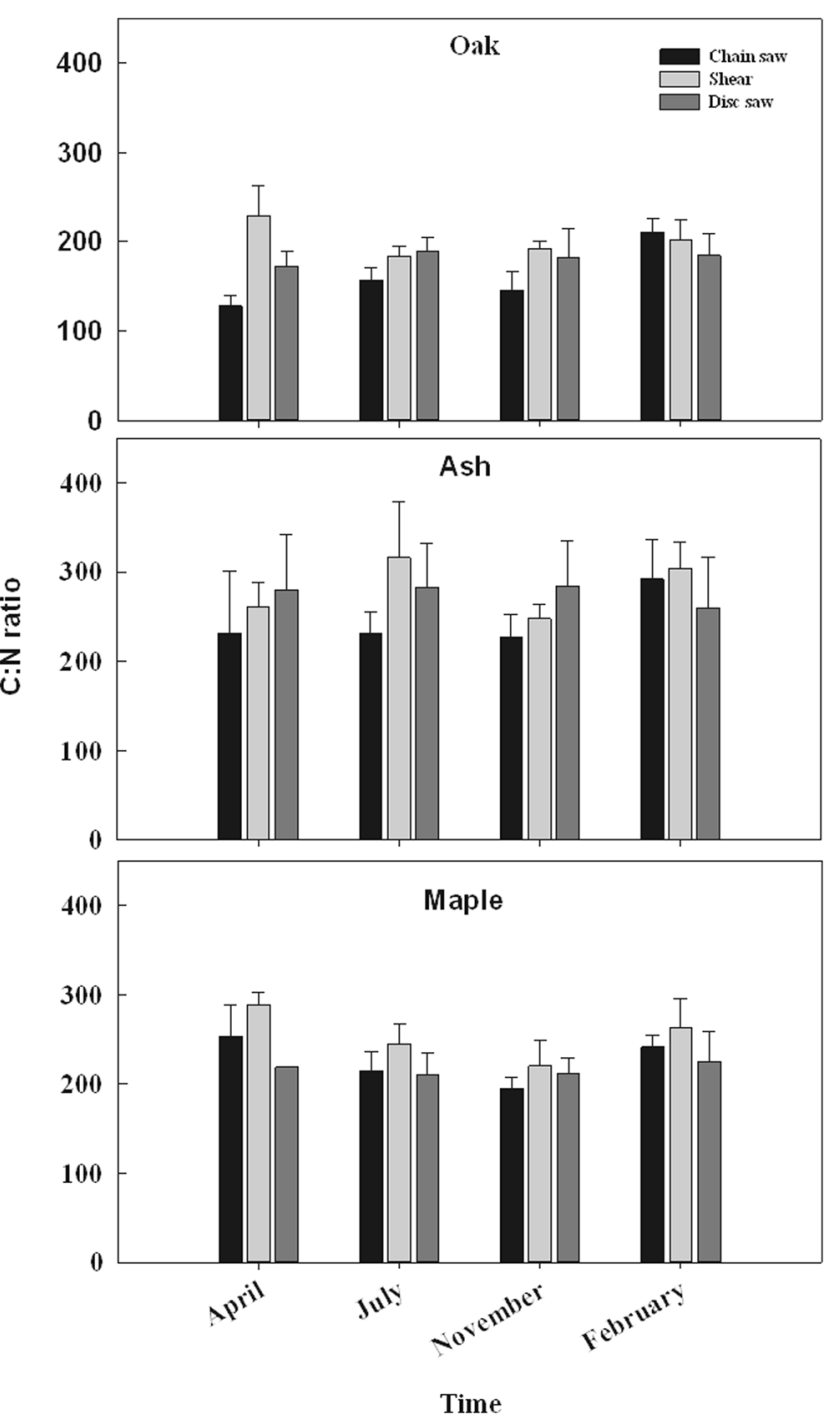

Fig. $5 \mathrm{C} / \mathrm{N}$ ratio in stumps by species, treatment, and month/ phenological phase. Note: phenological phases: April $=$ onset after cut, July $=$ exponential growth, November $=$ offset, February $=$ dormancy

the coppice stumps cut with a shear: between 20 (Spinelli et al. 2014b) and 70\% (Schweier et al. 2015).

Our study suggests that severe damage of this type - and especially stump pull - may result in increased stump mortality, as already found by other authors (De Souza et al. 2016, Ducrey and Turrel 1992). Fortunately, stump pull is relatively rare (6\% here) and it does not automatically result in death. In general, the levels of stump mortality recorded in this study are as low as those reported for manual cutting (Ducrey and Turrel 1992, Giudici and Zingg 2005) and lower than those reported for the mechanical cutting of aged oak coppice (14-16\%; Pyttel et al. 2013) or short-rotation eucalypt coppice (9-19\% De Souza et al. 2016). In the latter two cases, however, relatively high mortality was related to old stump age and inappropriate cutting season, respectively. Therefore, the low mortality levels recorded in this study might be considered typical of a healthy coppice forest managed according to good practice. 


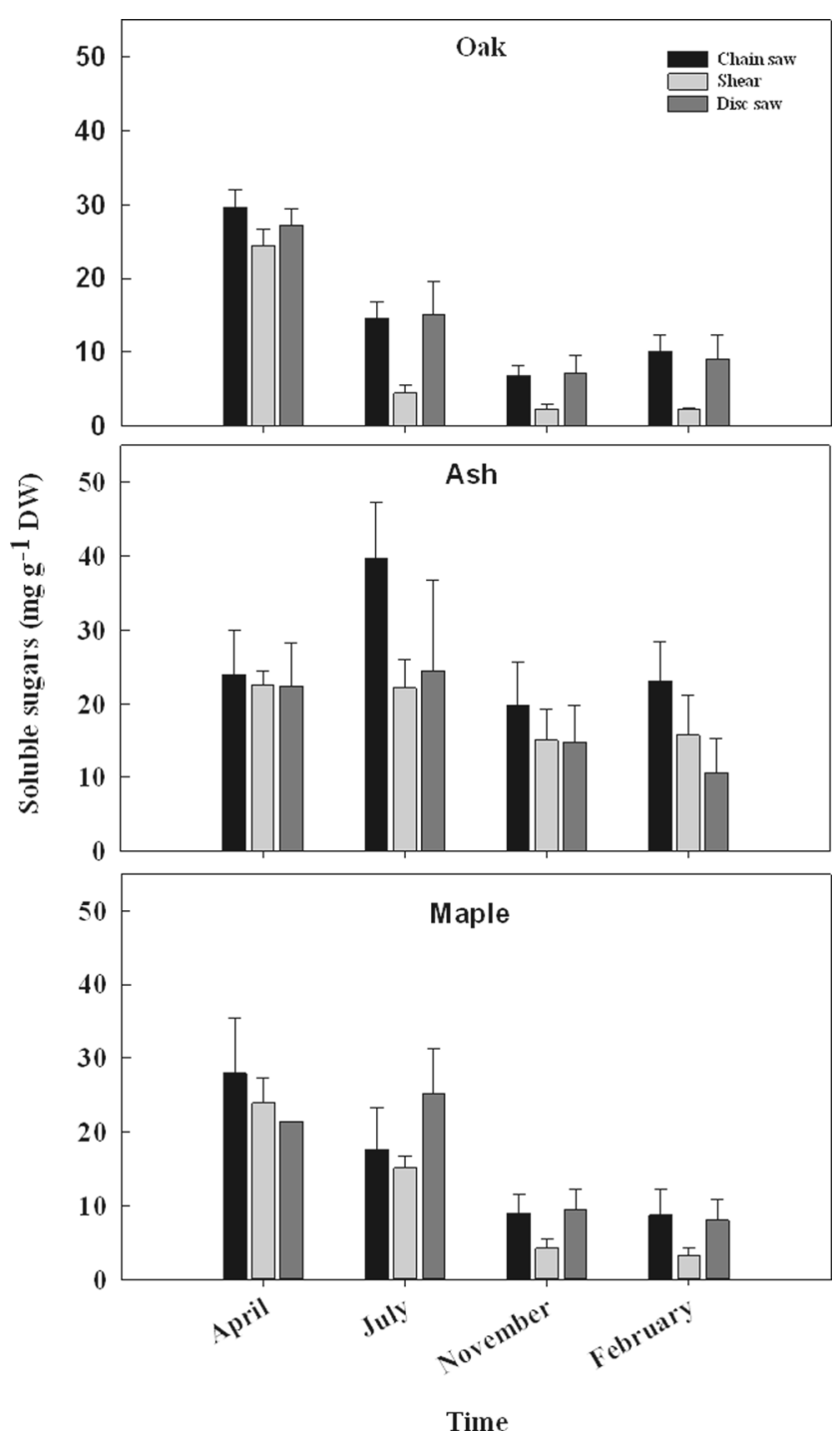

Fig. 6 Soluble sugar concentration in the stumps (mg soluble sugar per $\mathrm{g}$ of dry stump weight) by species, treatment, and month/phenological phase. Note: phenological phases: April $=$ onset after cut, July $=$ exponential growth, November $=$ offset, February $=$ dormancy

The height of dominant shoots has already proved a reliable indicator of overall stump vigor (Giudici and Zingg 2005, Pyttel et al. 2013), which supports our choice of indicators. Both the height and the diameter of the dominant shoots indicate that stump vigor is not affected by felling technology, and this statement is supported by the few works that appeared on this subject over the years (Crist et al. 1983, Ducrey and Turrel 1992, Pyttel et al. 2013, De Souza et al. 2016). If, at all, cutting with shears seems to prompt the emission of a larger number of shoots than obtained when cutting with a saw (Cabanettes and Pagès 1986, Hytönen 1994, De Souza et al. 2016), which was verified in our study as well. Our study also found that shoot vigor is directly related to stump size (i.e., circumference), as reported by Johnson (1975), Ducrey and Turrel (1992) and De Souza et al. (2016). Such finding may seem intuitive, but not all authors agree on that (McDonald and Powell 1983, Pyttel et al.
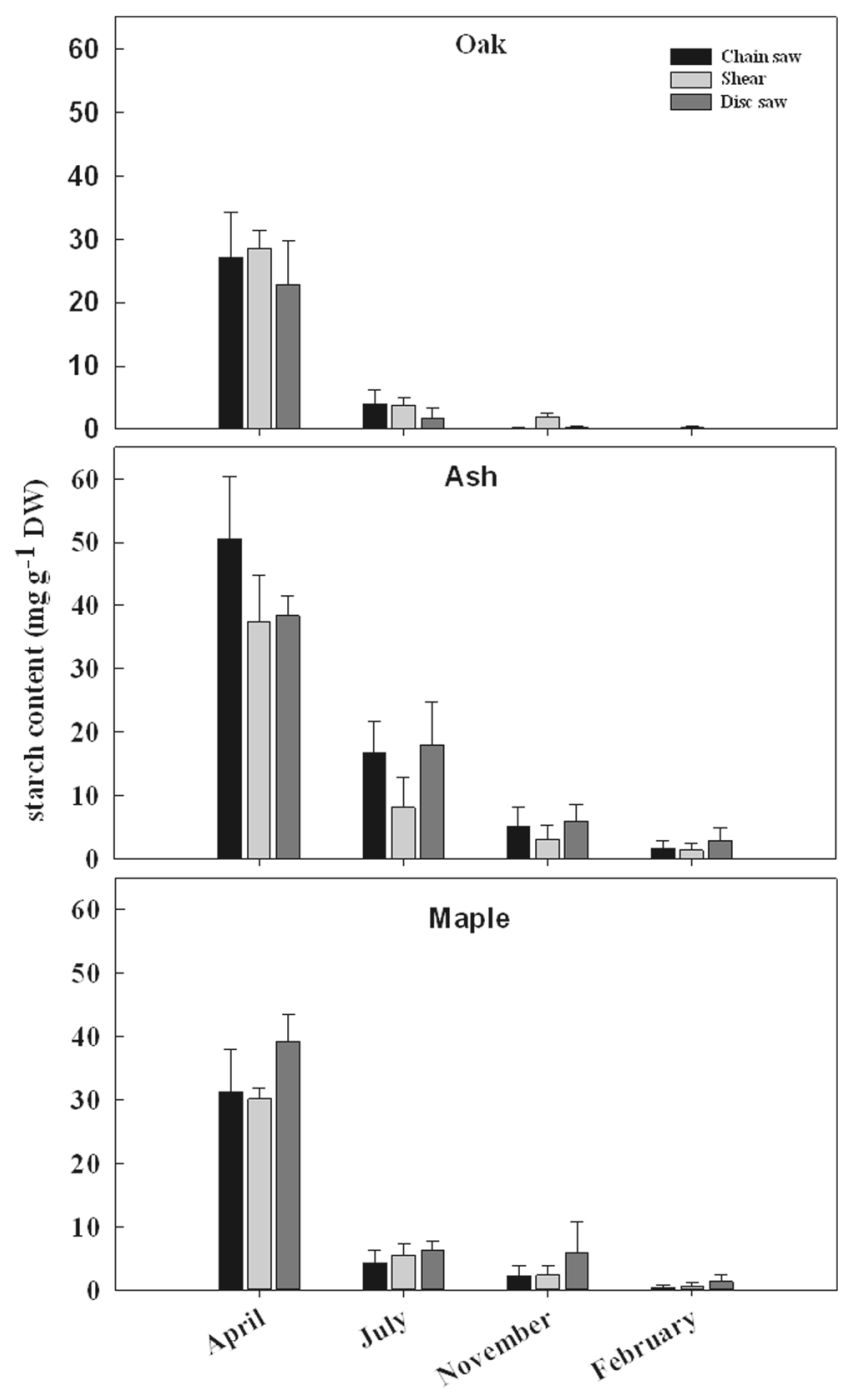

Time

Fig. 7 Starch concentration in the stumps (mg starch per g of dry stump weight) by species, treatment, and month/phenological phase. Note: phenological phases: April = onset after cut, July $=$ exponential growth, November $=$ offset, February $=$ dormancy

2013). Contradictory results may be attributed to the ambiguous character of stump size when used as an indicator: while large stump size may indicate vigor, it may also point to the old age of the parent tree, which results in decreased regeneration ability for some species (Matula et al. 2012).

Current bibliography presents more contradiction when it comes to the relationship between re-sprouting vigor and cutting height. While some authors state that a very low cutting height limits re-sprouting vigor (Cabanettes and Pagès 1986, Giudici and Zingg 2005, Harmer 2004), others support the opposite notion (Ducrey and Turrel 1992). Our findings place us with the large group of those who deny any relationship between cutting height and re-sprouting vigor (Piskoric 1963, Pyttel et al. 2013, Roth and Hepting 1943), despite the relatively large cutting height range explored in our study. 
During the first growing season, the carbon and nitrogen balance of the stumps were not affected by felling technique, indicating that mechanized felling had no detrimental effect on the vigor and nutrient status of the stumps in the short term. Unfortunately, current bibliography offers no other similar experiments that may be used for comparison with these results. Some authors postulate the existence of a linear relationship between the biomass produced after cutting and the carbon reserves in the stump (Waring and Pitman 1985). If that is the case, then re-sprouting vigor may be unaffected by felling technique, because that does not alter the nitrogen/carbon reserves in the stumps.

Regardless of cutting technology and species, the initial growth of shoots was associated with the mobilization of previously accumulated starch reserves, which strongly decreased between April and July. The involvement of soluble and insoluble energy reserves within the stumps and coarse roots during the re-sprouting has already been observed in Eucalyptus spp. (Wildy and Pate 2002) and Erica spp. (Paula and Ojeda 2009). On the contrary, $\mathrm{N}$ reserves stored in the sapwood did not seem involved in the re-sprouting process, because their concentration remained stable during that season. Our data confirm the assumption that $\mathrm{N}$ allocation to storage is regulated by plant phenology more than by environment or wounding (Millard and Grelet 2010). The amount of $\mathrm{N}$ stored in the sapwood was very similar to that found in $Q$, Petraea $\mathrm{L}$. (André and Ponette 2003), Q. robur L. (Penninckx et al. 2001), A. rubrum L. (Martin et al. 1998), and F. mandshurica Rupr. (Mei et al. 2015). Turkey oak had higher $\mathrm{N}$ content than did ash and maple, but this significant species effect may have resulted from a different stump size distribution.

The $\mathrm{C} / \mathrm{N}$ ratio can be considered a valuable index of the decomposition state of angiosperm wood (Weedon et al. 2009). After one growing season, the $\mathrm{C} / \mathrm{N}$ ratio of the stumps remained stable for all the felling treatments. Therefore, the high stump damage caused by the shear did not determine any significant changes in the nutrition substrate for decomposers, at least in the short term.

Taken together, the knowledge available on the subject indicates that the issue is quite complex, because coppice stands come in endless types and conditions, and many factors affect coppice regeneration. For this reason, one is hard put to produce general directions. Against this background, our study offers a remarkable insight into the effects of cutting technology on coppice regeneration. As far as one can tell, mechanical cutting does not increase stump mortality or reduce re-sprouting vigor. Of course, this is the result from the first growing season, and one still has to determine if the same trends will continue in the following years. However, the authors of past longer-term studies reported that early trends were maintained for at least 4 or 5 years, after which differences seemed to even out (Ducrey and Turrel 1992, Giudici and Zingg 2005, Harmer 2004). This study will continue in the next years, and if these findings will be confirmed, one may safely support the mechanization of coppice operations, with the benefits of improved financial sustainability and work safety. This will help unlocking the potential of coppice forests, which represent a large source of renewable biomass and may offer better resistance to the effects of climate change, compared with high forests (Spiecker 2003, Sjölund and Jump 2013).

Acknowledgements The authors acknowledge the financial support of the Italian Ministry for Agricultural, Food, and Forestry Policies (MIPAAF), within the scope of project Scientific Support to the Conversion of Conventional Agriculture Toward Energy Production (SUSCACE) and the technical support of COST Action FP1301 Eurocoppice. Thanks are also offered to the Università Agraria di Tarquinia for hosting the experiment; to Barili SAS for performing the harvest according to our instructions; and to Dr. F. Defrancesco, Dipl. Ing. C. Lombardini, and Mrs. M.L. Traversi for assisting with the data collection and analysis

\section{Compliance with ethical standards}

Funding The project was funded by the Italian Ministry for Agricultural, Food, and Forestry Policies (MIPAAF), within the scope of project Scientific Support to the Conversion of Conventional Agriculture Towards Energy Production (SUSCACE).

\section{References}

Albizu PM, Tolosana-Esteban E, Roman-Jordan E (2013) Safety and health in forest harvesting operations. Diagnosis and preventive actions. A review. Forest Syst 22:392-400

Amorini E, Bruschini S, Cutini A, Di Lorenzo M, Fabbio G (1998) Treatment of Turkey oak (Quercus cerris L.) coppices. Structure, biomass and silvicultural options. Annali dell'Istituto Sperimentale per la Selvicoltura 27, 121-129 ISSN 0390-0010

André F, Ponette Q (2003) Comparison of biomass and nutrient content between oak (Quercus petraea) and hornbeam (Carpinus betulus) trees in a coppice-with-standards stand in Chimay (Belgium). Ann For Sci 60:489-502

Bell J (2002) Changes in logging injury rates associated with use of fellerbunchers in West Virginia. J Saf Res 33:462-471

Buckley GP (1992) Ecology and management of coppice woodlands. Chapman \& Hall, London

Cabanettes A, Pagès L (1986) Effet des techniques de coupe sur la hauteur des cépées dans un taillis de châtaignier (Castanea sativa Mill). Can J For Res 16:1278-1282

Coppini M, Hermanin L (2007) Restoration of selective beech coppices: a case study in the Apennines (Italy). For Ecol Manag 249:18-27

Crist J, Mattson J, Winsauer S (1983) Effect of severing method and stump height on coppice growth. In: intensive plantation culture: 12 years research (Hansen EA, ed), USDA Forest Service gen. Tech Rep NC-91:58-63

D’Acqui L, Pucci A, Janik L (2010) Soil properties prediction of western Mediterranean islands with similar climatic environments by means of mid-infrared diffuse reflectance spectroscopy. Eur J Soil Sci 61: $865-876$ 
De Souza D, Gallagher T, Mitchell D, McDonald T, Smidt M (2016) Determining the effects of felling method and season of year on the regeneration of short rotation coppice. Int J For Eng 27:53-65

Deslauriers A, Beaulieu M, Balducci L, Giovannelli A, Gagnon M, Rossi S (2014) Impact of warming and drought on carbon balance related to wood formation in black spruce. Ann Bot 114:335-345

Ducrey M, Turrel M (1992) Influence of cutting methods and dates on stump sprouting in Holm oak (Quercus ilex L) coppice. Ann Sci For 49:449-464

Emiliani G, Traversi M, Anichini M, Giachi G, Giovannelli A (2011) Transcript accumulation dynamics of phenylpropanoid pathway genes in the maturing xylem and phloem of Picea abies during latewood formation. J Integr Plant Biol 53:783-799

Giovannelli A, Emiliani G, Traversi M, Deslauriers A, Rossi S (2011) Sampling cambial region and mature xylem for non structural carbohydrates and starch analyses. Dendrochron 29:177-182

Giudici F, Zingg A (2005) Sprouting ability and mortality of chestnut (Castanea sativa mill.) after coppicing. A case study. Ann For Sci 62:513-523

Glithero N, Wilson P, Ramsden S (2013) Prospects for arable farm uptake of short rotation coppice willow and miscanthus in England. Appl Energ 107:209-218

Hall R, Han HS (2006) Improvements in value recovery through low stump heights: mechanized versus manual felling. West J Appl For 21:33-38

Han HS, Renzie C (2005) Effect of ground slope, stump diameter and species on stump height for feller-buncher and chainsaw felling. Int J For Eng 16:81-88

Harmer R (2004) Restoration of neglected hazel coppice. Forestry Commission Information Note 56, Edinburgh, Scotland, UK $12 \mathrm{p}$

Hédl R, Kopecky M, Komàrek J (2010) Half a century of succession in a temperate Oakwood: from species-rich community to mesic forest. Divers Distrib 16:267-276

Hytönen J (1994) Effect of cutting season, stump height and harvest damage on coppicing and biomass production of willow and birch. Biomass Bioenerg 6:349-357

Jansen P, Kuiper L (2004) Double green energy from traditional coppice stands in the Netherlands. Biomass Bioenerg 26:401-402

Johnson PS (1975) Growth and structural development of red oak sprout clumps. For Sci 21:413-418

Kays S, Canham C (1991) Effect of time and frequency of cutting on hardwood root reserves and sprout growth. For Sci 37:524-539

Martin J, Kloeppel B, Schaefer T, Kimbler D, McNulty S (1998) Aboveground biomass and nitrogen allocation of ten deciduous southern Appalachian tree species. Can J For Res 28:1648-1659

Matula R, Svátek M, Kůrová J, Úradníček L, Kadavý J, Kneifl M (2012) The sprouting ability of the main tree species in central European coppices: implications for coppice restoration. Eur J For Res 131: $1501-1511$

McDonald J, Powell G (1983) Relationships between stump sprouting and parent-tree diameter in sugar maple in the 1st year following clear-cutting. Can J For Res 13:390-394

McEwan A, Magagnotti N, Spinelli R (2016) The effects of number of stems per stool on cutting productivity in coppiced eucalyptus plantations. Silva Fenn 50:1448 14 p

McNeel J, Czerepinski F (1987) Effect of felling head design on shearrelated damage on southern yellow pine. South J Appl For 11:3-6

Mei L, Xiong Y, Gu J, Wang Z, Guo,D (2015) Whole-tree dynamics of non-structural carbohydrate and nitrogen pools across different seasons and in response to girdling in two temperate trees. Oecolog 177: 333-344.

Millard P, Grelet G (2010) Nitrogen storage and remobilization by trees: ecophysiological relevance in a changing world. Tree Physiol 30: 1083-1095
Ollikainen M (2014) Forestry in bioeconomy — smart green growth for the humankind. Scand J For Res 29:360-366

Olsen E, Hossain M, Miller M (1998) Statistical comparison of methods used in harvesting work studies. Oregon State University, Forest Research Laboratory, Corvallis, OR Research Contribution n 23. p. 31

Paula S, Ojeda F (2009) Belowground starch consumption after recurrent severe disturbance in three resprouter species of the genus Erica. Bot $87: 253-259$

Penninckx V, Glineur S, Gruber W, Herbauts J, Meerts P (2001) Radial variations in wood mineral element concentrations: a comparison of beech and pedunculate oak from the Belgian Ardennes. Ann For Sci $58: 253-260$

Piskoric O (1963) The dynamics of height increment of coppice shoots of Evergreen oak. Sumarski List 87:122-133

Pyttel P, Fischer U, Suchomel C, Gärtner S, Bauhus J (2013) The effect of harvesting on stump mortality and re-sprouting in aged oak coppice forests. For Ecol Manag 289:18-27

Roth E, Hepting G (1943) Origin and development of the oak stump sprouts as affecting their likelihood to decay. J For 41:27-36

Schier G, Zasada J (1973) Role of carbohydrate riserve in the development of root suckers in Populus tremuloides. Can J For Res 3:243250

Schweier J, Spinelli R, Magagnotti N, Becker G (2015) Mechanized coppice harvesting with new smallscale feller-bunchers: results from harvesting trials with newly manufactured felling heads in Italy. Biomass Bioenerg 72:85-94

Sjölund J, Jump A (2013) The benefits and hazards of exploiting vegetative regeneration for forest conservation management in a warming world. For 86:503-513

Spiecker H (2003) Silvicultural management in maintaining biodiversity and resistance of forests in Europe-temperate zone. J Environ Manag 67:55-65

Spinelli R, Cuchet E, Roux P (2007) A new feller-buncher for harvesting energy wood: results from a European test programme. Biomass Bioenerg 31:205-210

Spinelli R, Ebone A, Gianella M (2014a) Biomass production from traditional coppice management in northern Italy. Biomass Bioenerg 62:68-73

Spinelli R, Brown M, Giles R, Huxtable D, Laina-Relaño R, Magagnotti N (2014b) Harvesting alternatives for mallee agroforestry plantations in Western Australia. Agrofor Syst 88:479-487

Spinelli R, Cacot E, Mihelic M, Nestorovski L, Mederski P, Tolosana E (2016) Techniques and productivity of coppice harvesting operations in Europe: a metaanalysis of available data. Paper accepted for publication on Ann For Sci

Suchomel C, Spinelli R, Magagnotti N (2012) Productivity of processing hardwood from coppice forests. Croat J For Eng 33:39-47

Waring R, Pitman G (1985) Modifying lodgepole pine stands to change susceptibility to mountain pine beetle attack. Ecol 66:889-897

Weedon J, Cornwell W, Cornelissen J, Zanne A, Wirth C, Coomes D (2009) Global meta-analysis of wood decomposition rates: a role for trait variation among tree species? Ecol Lett 12:45-56

Wildy D, Pate J (2002) Quantifying above- and below-ground growth responses of western Australian oil mallee, Eucalyptus kochii subs. plenissima, to contrasting decapitation regimes. Ann Bot 90:185197

Wolfslehner B, Krajter S, Jovic D, Nestorovski L, Velichkov I (2009) Framing stakeholder and policy issues for coppice forestry in selected central and south-eastern European countries. Silva Balc 10:21-34 